\title{
Blood Cholinesterase Level is Associated with Cognitive Function in Indonesian School-age Children Exposed to Pesticides
}

\author{
Rusdy Ghazali Malueka ${ }^{1 *}$, Andrianor Rahman ${ }^{1}$, Ery Kus Dwianingsih², Andre Stefanus Panggabean ${ }^{1}$, \\ Halwan Fuad Bayuangga ${ }^{1}$, Sarastiti Alifaningdyah", Meutia Rizki Innayah ${ }^{1}$, Sri Awalia Febriana ${ }^{3}$, \\ Indarwati Setyaningsih ${ }^{1}$, Cempaka Thursina Srie Setyaningrum ${ }^{1}$, Abdul Gofir ${ }^{1}$, Sri Sutarni ${ }^{1}$, Ismail Setyopranoto \\ ${ }^{1}$ Department of Neurology, Faculty of Medicine, Public Health and Nursing, Universitas Gadjah Mada, Dr Sardjito General \\ Hospital, Yogyakarta, Indonesia; ${ }^{2}$ Department of Anatomical Pathology, Faculty of Medicine, Public Health and Nursing, \\ Universitas Gadjah Mada, Dr Sardjito General Hospital, Yogyakarta, Indonesia; ${ }^{3}$ Department of Dermatology and Venereology, \\ Faculty of Medicine, Public Health and Nursing, Universitas Gadjah Mada, Dr Sardjito General Hospital, Yogyakarta, Indonesia
}

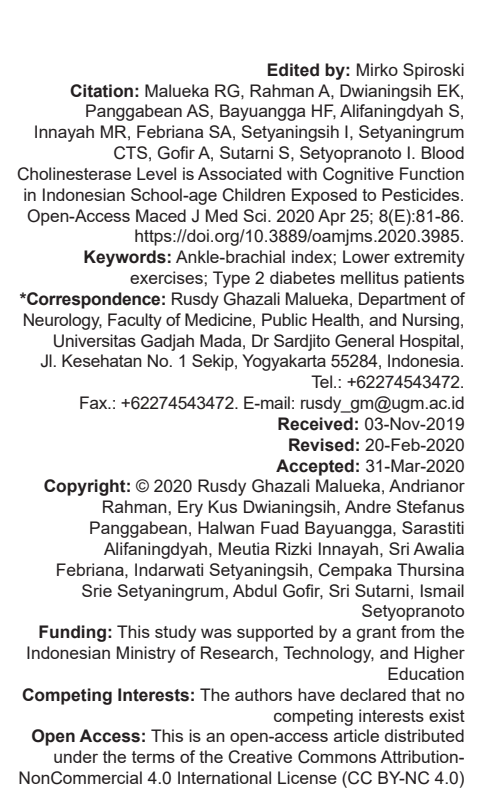

\section{Abstract}

BACKGROUND: Pesticides are known as depressors of acetylcholinesterase (AChE) activity, resulting in the nervous system toxicity. The previous studies have described associations between AChE, a stable marker of pesticide poisoning, and cognitive performance in children.

AIM: This study aimed to identify the association between blood AChE level and cognitive function in children exposed to pesticides in the Magelang Regency, Indonesia.

METHODS: A cross-sectional study involving school-age children with a history of pesticide exposure in Ngablak Magelang Regency, Central Java, Indonesia, was conducted. Blood AChE level was evaluated, and the Modified Mini-Mental State Examination for Children (MMMSEC) was used to analyze the cognitive function of the children.

RESULTS: In total, 56 subjects aged between 9 and 11 years were included in this study. Median blood AChE level was $9.64 \mathrm{kIU} / \mathrm{L}$, and 24 subjects $(42.9 \%)$ had low blood AChE levels. Median MMMSEC score was 33 . Eleven subjects (19.6\%) were found to have abnormal cognitive function. Bivariate analysis showed that blood AChE leve was associated with MMMSEC score $(r=0.343, p=0.010)$. Multiple linear regression showed that blood AChE level had a positive association with cognitive function in children, assessed using the MMMSEC score $(\beta=0.360$ $p=0.006$ ). Further analysis showed that the attention and orientation (memory function) domains of the MMMSEC were significantly associated with blood AChE level ( $\beta$ : 0.371 and 0.297 , respectively, $p<0.05$ )

CONCLUSIONS: Blood AChE level, a stable marker of pesticide poisoning, was positively associated with cognitive function in children, as assessed using the MMMSEC score. In particular, the orientation and attention domains of the MMMSEC were associated with blood AChE level.

\section{Introduction}

Indonesia is an agricultural country and approximately 40 million of its population work in the agricultural sector. The Indonesian government promotes the use of pesticides to increase the production of agricultural goods. As such, the use of pesticides in Indonesia shows an annual increase of approximately 6-20\% [1], [2]. A previous study showed that the most common pesticides used by Indonesian farmers are organophosphates [3]. Cholinesterase inhibitors (organophosphates and carbamates) are known to reduce the activity of acetylcholinesterase (AChE), the primary enzyme responsible for the metabolism of acetylcholine [4]. The inhibition of AChE causes an increase in synaptic acetylcholine concentration, leading to nicotinic and muscarinic symptoms, and central peripheral nervous system toxicity [3].

Children are particularly vulnerable to pesticide intoxication. In agricultural areas, children can be exposed to pesticides by helping their parents on farms [2], or by simply living in agricultural communities that use pesticides (non-occupational pesticide exposure) [5]. Chronic and subacute pesticide exposure has been shown to affect neurobehavioral performance. The previous cohort studies have described positive associations between AChE activity and neurobehavioral performance [4], [5]. Furthermore, prenatal organophosphate exposure has been shown to be associated with mental and motor developmental retardation, general developmental disorders, and reduced attention, working memory, and intelligence in children [4]. This early exposure 
can also cause spatial memory disturbances, reduced cognitive learning capacity, and reduced motor performance [6]. Organophosphate exposure during pregnancy can interfere with embryonic development, causing premature labor, or low infant birth weight [7]. Exposure after birth has been shown to result in a greater risk of attention-deficit/hyperactivity disorder (ADHD) behaviors and neurodevelopmental deficits, notably in attention, working memory, learning, and inhibitory control. However, these effects have been observed in boys only [4]. Cognitive impairment related to chronic pesticide exposure is more significant in children than in adults [8], primarily because the developing brain is more vulnerable to pesticide intoxication [9], [10], [11].

Pesticides such as organophosphates have short half-lives in the blood ( $<1$ day), making it difficult to directly calculate their level in blood or urine [4]. Therefore, another marker by which the level of pesticide exposure can be detected is required. Reduced AChE activity is a stable marker of pesticide poisoning, and a prior study reported that pesticide exposure in children can be predicted by calculating AChE activity [5]. In the central nervous system, AChE is primarily found at the cholinergic synapses and neuromuscular junctions. Acetylcholine is released from the pre-synaptic terminal and acts on acetylcholine receptors on the post-synaptic membrane, inducing a wide range of effects. AChE terminates this synaptic transmission by hydrolyzing acetylcholine into acetate and choline. This reduction of continuous nerve transmission at nerve endings by AChE is necessary for normal functioning of the central and peripheral nervous systems [12]. After organophosphate exposure, brain AChE was reduced in rats [4]. AChE is also found in the membranes of erythrocytes [12]. This erythrocytic AChE is homologous to neuronal AChE - both exhibit low intra-individual variability, a long recovery time (82 days), and function as stable indicators of past exposure to cholinesterase inhibitors [4].

A review of epidemiological studies concluded that no studies strongly implicate any particular pesticide as causing adverse neurodevelopmental effects in infants and children [11]. Therefore, further studies are required to assess this association between pesticide exposure and neurodevelopment.

This study aimed to identify the correlation between blood AChE level, a stable indicator of pesticide poisoning, and cognitive function in children in Ngablak, a district in the Magelang Regency, Central Java, Indonesia. This area was chosen because a previous study showed that $99.8 \%$ of farmers in this area had mild to severe pesticide intoxication [13]. However, no research has been conducted into the effect of pesticides on children in this area.

\section{Materials and Methods}

\section{Subject selection}

A cross-sectional study on the correlation between blood AChE level and cognitive function in school-age children exposed to pesticides was conducted. This study was approved by the Ethical Committee of the Faculty of Medicine, Universitas Gadjah Mada, Yogyakarta, Indonesia. One of the villages in the Ngablak District, Seloprojo village, was randomly selected, and all children in this village who satisfied the inclusion criteria were included in the study. The inclusion criteria were: (1) A history of pesticide exposure; (2) aged between 9 and 11 years old; and (3) consent from their parents to join the study, demonstrated by completion of an informed consent form. The exclusion criteria were: (1) Children with severe acute or chronic diseases; (2) a history of significant head trauma; and (3) congenital defects. A history of pesticide exposure was determined using previously described criteria [14]. The minimum sample size calculated using the formula for calculating the sample size for correlative analysis of numerical data was 52 subjects.

\section{Measurement of variables}

To measure erythrocytic AChE levels, blood samples were collected using $3 \mathrm{~mL}$ Vacutainer ${ }^{\circledR}$ tubes, which were then immediately placed on ice and transported to a private laboratory to be analyzed. Normal blood AChE level was considered to be between 9.572 and $15.931 \mathrm{kIU} / \mathrm{L}$. The samples were examined using Ellman's reagent (DTNB), as described previously [15].

Cognitive function was measured using the Modified Mini-Mental State Examination for Children (MMMSEC) questionnaire, a modified form of the MMSE for children. This test includes several domains of cognitive functions, namely, orientation, attention, registration, recall, and language. The MMMSEC has been shown to have good inter-observer reliability. This questionnaire has a maximum score of 37 points, and the cutoff point for an abnormal MMMSEC score in 9-11 year old children is 30 [16], [17].

Other confounding factors were collected using a questionnaire, namely, age, sex, parental education level, economic status, and pesticide exposure history. It has been shown that combining blood AChE level and a questionnaire about the history of exposure are sufficient to assess organophosphate exposure [18]. The nutritional status of each child was assessed by measuring their weight and height and subsequently calculating body mass index. Economic status was determined based on parental monthly income - a monthly income greater than the local minimum wage was considered high. 


\section{Statistical analysis}

The associations between all independent variables and the dependent variable (MMMSEC score) were analyzed using bivariate analysis. Normality test using the Shapiro-Wilk test was done first. The data that met the criteria for parametric analysis were analyzed by paired t-test or one-way ANOVA. The data that did not meet the criteria for parametric analysis were analyzed using Mann-Whitney test or Kruskal-Wallis test. The correlation between blood AChE level and MMMSEC score was determined using Pearson's correlation for normally distributed data and Spearman's correlation for non-normally distributed data. Multivariate analysis using multiple linear regressions was conducted to further analyze factors with $p<0.25$ in the bivariate analysis. $p<0.05$ was considered statistically significant.

\section{Results}

\section{Subject characteristics}

Fifty-six subjects aged between 9 and 11 years old were included in this study (Table 1). Of these children, $48.2 \%$ were 10 years old. There were slightly more female than male participants ( $55.4 \%$ and $44.6 \%$, respectively). Twenty-four subjects (42.9\%) had a low blood AChE level. Median blood AChE level was $9.64 \mathrm{kIU} / \mathrm{L}$.

Table 1: Subject characteristics $(n=56)$

\begin{tabular}{|c|c|c|c|}
\hline Variable & $\mathrm{n}(\%)$ & $\begin{array}{l}\text { Median } \\
\text { (Minimum-Maximum) }\end{array}$ & $\begin{array}{l}95 \% \text { confidence } \\
\text { interval }\end{array}$ \\
\hline Age (years) & - & $10(9-11)$ & $9.73-10.10$ \\
\hline Sex & - & - & - \\
\hline Male & $25(44.6)$ & - & - \\
\hline Female & $31(55.4)$ & - & - \\
\hline Father's education level & - & - & - \\
\hline Senior high school or higher & $3(5.4)$ & - & - \\
\hline Below senior high school & $53(94.6)$ & - & - \\
\hline Mother's education Level & - & - & - \\
\hline Senior high school or higher & $3(5.4)$ & - & - \\
\hline Below senior high school & $53(94.6)$ & - & - \\
\hline Father's occupation & - & - & - \\
\hline Farmer & $47(83.9)$ & - & - \\
\hline Other & $9(16.1)$ & - & - \\
\hline Mother's occupation & - & - & - \\
\hline Farmer & $34(60.7)$ & - & - \\
\hline Other & $22(39.3)$ & - & - \\
\hline Economic status & - & - & - \\
\hline High & $3(5.4)$ & - & - \\
\hline Low & $53(94.6)$ & - & - \\
\hline Nutritional status (BMI) & - & - & - \\
\hline Wasted & $1(1.8)$ & - & - \\
\hline Normal & $47(83.9)$ & - & - \\
\hline Obese & $8(14.3)$ & - & - \\
\hline Blood cholinesterase level (kIU/L) & - & $9.64(7.71-13.93)$ & $9.74-10.49$ \\
\hline Normal & $32(57.1)$ & - & - \\
\hline Below normal & $24(42.9)$ & - & - \\
\hline MMMSEC score & - & $33(22-37)$ & $31.92-33.81$ \\
\hline Normal & $45(80.4)$ & - & - \\
\hline Below normal & $11(19.6)$ & - & - \\
\hline
\end{tabular}

The MMMSEC cutoff point for 9-11 year old children was 30 points. Eleven subjects (19.6\%) had abnormal cognitive function based on this cutoff point, while the other 45 subjects had normal scores. Median MMMSEC score was 33 , with minimum and maximum recorded values of 22 and 37 , respectively.

\section{Statistical analysis}

Bivariate analysis was used to determine the correlation between blood AChE level and MMMSEC score. The correlation coefficient $(r)$ was 0.343 and $p=0.010(p<0.05)$, meaning that blood AChE level positively and significantly correlated with MMMSEC score. The analysis of other confounding factors (age, sex, nutritional status, parents' education level, and economic status) did not show any significant associations $(p>0.05)$ (Table 2$)$.

Table 2: Bivariate analysis of factors affecting MMMSEC

\begin{tabular}{lllll}
\hline Variable & $\begin{array}{l}\text { Mean MMMSEC } \\
(\mathrm{SD})\end{array}$ & $\mathrm{R}$ & $\mathrm{p}$ & $\begin{array}{l}\text { Mean differences } \\
(95 \% \mathrm{Cl})\end{array}$ \\
\hline Age (years) & - & -0.060 & 0.661 & - \\
Sex & - & - & - & - \\
Male & $32.32(3.30)$ & - & 0.173 & $-2.84-0.838$ \\
Female & $33.32(3.50)$ & - & - & - \\
Father's education level & - & - & - & - \\
Senior high school or higher & $31(0)$ & - & 0.593 & $1.01-2.94$ \\
Below senior high school & $32.98(3.48)$ & - & - & - \\
Mother's education level & - & - & - & - \\
Senior high school or higher & $31(0)$ & - & 0.593 & $1.01-2.94$ \\
Below senior high school & $32.98(3.48)$ & - & - & - \\
Father's occupation & - & - & - & - \\
Farmer & $32.80(3.57)$ & - & 0.955 & $-2.93-2.10$ \\
Other & $33.22(3.5)$ & - & - & - \\
Mother's occupation & - & - & - & - \\
Farmer & $33.17(3.38)$ & - & 0.344 & $-1.11-2.65$ \\
Other & $32.40(3.5)$ & - & - & - \\
Economic status & - & - & - & - \\
High & $34.33(1.52)$ & & 0.532 & $-5.62-2.54$ \\
Low & $32.79(3.48)$ & & - & - \\
Nutritional status (BMI) & - & - & - & - \\
Wasted & $34(0)$ & - & 0.356 & - \\
Normal & $32.65(3.36)$ & - & - & - \\
Obese & $34.00(3.96)$ & - & - & - \\
Blood cholinesterase level & - & 0.343 & $0.010^{*}$ & - \\
(KUIL) & & & &
\end{tabular}

Blood ch

(kIU/L)

MMMSEC: Modified Mini-Mental State Examination for children, BMI: Body mass index, $p<0.05$ was considered statistically significant $\left(^{*}\right)$

Multiple linear regression showed that blood AChE level was positively associated with cognitive function in children, as assessed using the MMMSEC score $(\beta=0.360 ; p=0.006)$ (Table 3 ).

Table 3: Multivariate analysis of MMMSEC score

\begin{tabular}{lllll}
\hline Variable & $\mathrm{B}$ & $\mathrm{SE}_{\mathrm{B}}$ & $\beta$ & $\mathrm{p}$ \\
\hline Blood cholinesterase level $(\mathrm{kIU} / \mathrm{L})$ & 0.793 & 0.279 & 0.360 & $0.006^{*}$ \\
\hline $\begin{array}{l}\mathrm{B}=\text { Unstandardized regression coefficient; } \mathrm{SE}_{\mathrm{g}}=\text { Standard error of coefficient; } \beta=\text { Standardized coefficient; } \\
\mathrm{p}<0.05 \text { was considered statistically significant }\left({ }^{*}\right) .\end{array}$
\end{tabular}

Further analysis was conducted to determine which cognitive domain of the MMMSEC was affected the most by decreased blood AChE level. Bivariate and multivariate analyses were performed to determine the effect of AChE level and other confounding variables on each domain of cognitive function. A summary of the results is shown in Table 4. The MMMSEC attention domain, assessed by the backward digit span task, and orientation domain were significantly associated with blood AChE level ( $\beta$ : 0.371 and 0.297 , respectively, $p<0.05$ ).

\section{Discussion}

This study demonstrated that blood AChE level, a stable marker of pesticide poisoning, was positively associated with cognitive function in children, particularly with respect to the orientation 
Table 4: Multivariate analysis of the association between cholinesterase level and each domain of the MMMSEC

\begin{tabular}{lllll}
\hline MMMSEC domain & $\mathrm{B}$ & $\mathrm{SE}_{\mathrm{B}}$ & $\beta$ & $\mathrm{p}$ \\
\hline Orientation & 0.252 & 0.107 & 0.297 & $0.023^{*}$ \\
Attention (forward digit span task) & 0.133 & 0.085 & 0.209 & 0.123 \\
Attention (backward digit span task) & 0.330 & 0.109 & 0.371 & $0.004^{*}$ \\
Registration & 0.026 & 0.016 & 0.217 & 0.109 \\
Recall memory & 0.100 & 0.101 & 0.135 & 0.326 \\
Language & 0.006 & 0.025 & 0.034 & 0.805 \\
Visuospatial & 0.013 & 0.012 & 0.151 & 0.265 \\
\hline B=Unstandardized regression coefficient; SEB=Standard error of coefficient; $\beta=$ Standardized coefficient;
\end{tabular}

(

and attention domains of the MMMSEC. This result indicated the lower a child's blood AChE level, the poorer their cognitive function, and notably memory function and attention. This is consistent with a previous study by Lizardi et al. [8], who demonstrated a correlation between increased organophosphate metabolite levels, specifically dialkyl phosphate metabolites, and cognitive deficits in attention speed, sequencing, mental flexibility, and concept formation. In addition, another study reported that reduced AChE activity correlated with neurodevelopmental deficits in attention, inhibitory control, memory, and probably language. This was observed in apparently healthy boys, but not girls [4]. Similarly, a systematic review of 27 studies conducted by Munoz-Quezada et al. [18] identified pesticide exposure-associated attention and memory problems in ten longitudinal studies.

Organophosphates can be detected in the amniotic fluid and can pass through the placental barrier, thus endangering the development of the fetal brain [19]. Indeed, the previous studies have reported neurobehavioral delays in children with early life exposure to commonly applied agricultural pesticides [5], [19]. Organophosphate exposure in early life has also been associated with symptoms of ADHD, including reduced attention and inhibitory control [5]. Another study showed that higher prenatal organophosphate exposure, measured using umbilical cord blood plasma, was associated with lower full-scale $\mathrm{IQ}$ and working memory in children aged 7 years old from an urban minority [19].

Rauh et al. performed magnetic resonance imaging on 40 children exposed prenatally to the organophosphate pesticide chlorpyrifos (CPF) and demonstrated alterations in brain morphology [20]. They noted regional enlargement of the superior temporal gyrus, posterior middle temporal gyrus, bilateral inferior postcentral gyri, superior frontal gyrus, gyrus rectus, cuneus, and precuneus along the mesial wall of the right hemisphere. These cortical regions control executive functions, including attention and inhibitory control. Another study by the same group showed that organophosphate exposure caused cognitive disturbance, which could be explained by the prefrontal cortical thinning observed in the highexposure children [19].
This study showed that pesticides can cause impaired cognitive function by inhibiting $\mathrm{AChE}$, an enzyme necessary for the regulation of acetylcholine neurotransmission. The cholinergic system has an important function in brain development. This AChE inhibition is thought to be mediated by direct toxic effects on neurons and glia [4], [5]. Studies in rats have shown that organophosphate pesticides inhibit the activity of brain AChE, especially in the hippocampus, a brain region with an important role in imagination, spatial navigation, and memory [4]. Early developmental exposure to CPF in animal models is cytotoxic to both neurons and glia. The signs of this neuronal damage include excessive perikaryal and astrocytic swelling, which subsequently lead to astrogliosis and glial scarring. In animals, changes in neuronal cell replication, apoptosis, and cortical lamination were all noted as direct neurotoxic effects of early CPF organophosphate exposure [20]. Further studies need to be done to clarify whether the same effects also happen in human.

This is the first study to investigate the effect of pesticide exposure on children's cognitive function in an Indonesian population. The previous studies have shown that certain genetic polymorphisms may affect the metabolism of organophosphates, indicating that some populations may be more vulnerable to the neurodevelopmental effects of pesticide exposure than others [21]. Therefore, this study is significant as it is the first to show that pesticide exposure is associated with reduced cognitive function in Indonesian children. Further studies need to be conducted to identify genetic polymorphisms within the Indonesian population.

There exist several limitations of this study. First, we did not consider the length of time since the subjects' last exposure to pesticides and how this relates to blood AChE level. The timing of pesticide exposure is known to have an effect on the occurrence of neurobehavior disorders. A previous study showed that the closer the examination time to the time of pesticide exposure, the lower the child's neurobehavioral value, especially with respect to attention, inhibition control, and visuospatial and sensorimotor processing [5]. This is consistent with studies in animals which have reported that neurobehavioral disorders caused by pesticide exposure are reversible. A study in rats showed an early decrease in attention during a 14-day period of CPF organophosphate exposure, followed by a linear correction of attention function, which then returned to normal 30 days after the exposure [5]. The second limitation of this study is that several other factors that can affect cognitive function in children were not analyzed, such as iodine deficiency [22]. We also did not analyze the frequency and duration of pesticide exposure in these children. 


\section{Conclusion}

This study demonstrated that blood AChE level, a stable marker of pesticide poisoning, was positively associated with cognitive function in children, as assessed using the MMMSEC score. In particular, the orientation and attention domains of the MMMSEC were associated with blood AChE level. Therefore, future studies with a larger scale should be conducted into this relationship and pesticide regulation should be introduced in Indonesia.

\section{Acknowledgment}

The authors would like to thank all of the residents at the Department of Neurology, Universitas Gadjah Mada for their help during the study.

\section{References}

1. Djunaedy A. Biopestisida sebagai pengendali organisme pengganggu tanaman (OPT) yang ramah lingkungan. Embryo. 2009;6(1):88-95.

2. Hidayah N, Suhartono, Endahwahyuningsih N, Apoina, Budiono. Riwayat paparan pestisida dan kadar insulin like growth factor I (IGF-1) pada siswa SD negeri Dukuhlo 01 kecamatan Bulakamba kabupaten Brebes. J Health Educ. 2016;l(1):26-32. https://doi.org/10.14710/jkli.15.2.42-45

3. Perwitasari DA, Prasasti D, Supadmi W, Jaikishin SA, Wiraagni IA. Impact of organophosphate exposure on farmers health in Kulon Progo, Yogyakarta: Perspectives of physical, emotional and social health. SAGE Open Med. 2017;5:1-6. https://doi.org/10.1177/2050312117719092

PMid:28839934

4. Suarez-Lopez JR, Himes JH, Jacobs DR Jr., Alexander BH, Gunnar MR. Acetylcholinesterase activity and neurodevelopment in boys and girls. Pediatrics. 2013;132(6):1649-58. https://doi. org/10.1542/peds.2013-0108

PMid:24249815

5. Suarez-Lopez JR, Checkoway H, Jacobs DR Jr., Al-Delaimy WK, Gahagan S. Potential short-term neurobehavioral alterations in children associated with a peak pesticide spray season: The mother's day flower harvest in Ecuador. Neurotoxicology. 2017;60:125-33. https://doi.org/10.1016/j.neuro.2017.02.002 PMid:28188819

6. Miswon NH, Hashim Z, How V, Chokeli R. Blood cholinesterase level and learning ability of primary school children in an agricultural village, Tanjung Karang, Malaysia. $\mathrm{Br} J$ Med Med Res. 2015;8(1):52-60. https://doi.org/10.9734/ bjmmr/2015/16804

7. Kapka-Skrzypczak L, Sawicki K, Czajka M, Turski WA, Kruszewski M. Cholinesterase activity in blood and pesticide presence in sweat as biomarkers of children's environmental exposure to crop protection chemicals. Ann Agric Environ Med. 2015;22(3):478-82. https://doi.org/10.5604/12321966.1167718

\section{PMid:26403119}

8. Lizardi PS, O'Rourke MK, Morris RJ. The effects of organophosphate pesticide exposure on Hispanic children's cognitive and behavioral functioning. J Pediatr Psychol. 2008;33(1):91-101. https://doi.org/10.1093/jpepsy/jsm047 PMid: 17569709

9. London L, Beseler C, Bouchard MF,Bellinger DC, Colosio C, Grandjean P, et al. Neurobehavioral and neurodevelopmental effects of pesticide exposures. Neurotoxicology. 2012;33(4):88796. https://doi.org/10.1016/j.neuro.2012.01.004

PMid:22269431

10. Hamzah NA, Hashim Z, Miswon N, Baguma D. Blood cholinesterase level and cognitive functioning among primary school children near paddy field in Tanjung Karang, Selangor. Aust J Basic Appl Sci. 2015;9(22):49-55.

11. Burns CJ, Mclntosh LJ, Mink PJ, Jurek AM, Li AA. Pesticide exposure and neurodevelopmental outcomes: Review of the epidemiologic and animal studies. J Toxicol Environ Health B Crit Rev. 2013;16(3-4):127-283. https://doi.org/10.1080/109374 04.2013 .783383

PMid:23777200

12. Lionetto MG, Caricato R, Calisi A, Giordano ME, Schettino T. Acetylcholinesterase as a biomarker in environmental and occupational medicine: New insights and future perspectives. Biomed Res Int. 2013;2013:321213. https://doi. org/10.1155/2013/321213

PMid:23936791

13. Prijanto TB. Analisis Faktor Risiko Keracunan Pestisida Organofosfat Pada Keluarga Petani Holtikultura di Kecamatan Ngablak Kabupaten Magelang. Indonesia: Universitas Diponegoro; 2009.

14. Rasipin. Faktor-faktor Yang Berhubungan Dengan Kejadian Goiter Pada Siswa-Siswa SD di Wilayah Pertanian (Penelitian di Kecamatan Buakamba Kabupaten Brebes). Master's Thesis. Indonesia: Universitas Diponegoro; 2011. https://doi. org/10.14710/jkli.16.1.22-28

15. Ellman GL, Courtney KD, Andres V, Featherstone RM. A new and rapid colorimetric determination of acetylcholinesterase activity. Biochem Pharmacol. 1961;7(2):88-95. https://doi. org/10.1016/0006-2952(61)90145-9

PMid: 13726518

16. Jain M, Passi GR. Assessment of a modified mini-menta scale for cognitive functions in children. Indian Pediatr. 2005;42(9):907-12.

PMid: 16208050

17. Thursina C, Ar Rochmah M, Nurputra DK, Harahap IS Harahap NI, Sa'Adah N, et al. Attention deficit/hyperactivity disorder (ADHD): Age related change of completion time and error rates of Stroop test. Kobe J Med Sci. 2015;61(1):E19-26. PMid:25868610

18. Muñoz-Quezada MT, Lucero BA, Barr DB, Steenland $K$, Levy K, Ryan PB, et al. Neurodevelopmental effects in children associated with exposure to organophosphate pesticides: A systematic review. Neurotoxicology. 2013;39:15868. https://doi.org/10.1016/j.neuro.2013.09.003 PMid:24121005

19. Rauh V, Arunajadai S, Horton M, Perera F, Hoepner L, Barr DB, et al. Seven-year neurodevelopmental scores and prenatal exposure to chlorpyrifos, a common agricultural pesticide. Environ Health Perspect. 2011;119(8):1196-201. https://doi. org/10.1201/b18221-17

PMid:21507777

20. Rauh VA, Perera, FP, Horton MK, Whyatt RM, Bansal R, Hao $\mathrm{X}$, et al. Brain anomalies in children exposed prenatally to a common organophosphate pesticide. Proc Natl Acad 
Sci USA. 2012;109(20):7871-876. https://doi.org/10.1073/ pnas. 1203396109

PMid:22547821

21. Berkowitz GS, Wetmur JG, Birman-Deych E, Obel J, Lapinski RH Godbold $\mathrm{JH}$, et al. In utero pesticide exposure, maternal paraoxonase activity, and head circumference. Environ Health
Perspect. 2004;112(3):388-91. https://doi.org/10.1289/ehp.6414 PMid:14998758

22. Gastaldi R, Muraca M, Beltramo A, Poggi E. lodine deficiency and its consequences for cognitive and psychomotor development of children. Ital J Pediatr. 2014;40(1):A15. https:// doi.org/10.1186/1824-7288-40-s1-a15 